\title{
Police Perception of Migration and Migrants in Greece
}

\author{
Georgios A. Antonopoulos, John Tierney and Colin Webster* \\ Senior lecturer in criminology, University of Teesside, UK, \\ e-mail: g.aantonopoulos@tees.ac.uk; \\ Senior lecturer in criminology, University of Durham, UK, \\ e-mail: john.tierney@durham.ac.uk; \\ Reader in criminology, Leeds Metropolitan University, UK, \\ e-mail: c.webster@leedsmet.ac.uk
}

\section{Introduction}

The beginning of the I990s saw a sharp rise in the number of immigrants entering Greece from a variety of contexts. Drawing on notions of ethnicity and immigration, the phenomenon of migration into Greece became a topic of heated debate, and was increasingly identified with a range of "social problems" such as unemployment, national (in)security and, of course, crime. Events such as 9/II in the US, $7 / 7$ in Britain, and the 2005 riots in the suburbs of Paris and other French cities, although occurring in other contexts, had a global resonance and heightened these debates. The relationship between migrants and crime in particular has been an important issue in the social and political agenda of Greece with some intermissions. "Organised crime" in the country, for example, had been considered to be unknown before the beginning of the I990s; nowadays the dominant view among social and political commentators, as well as Greek citizens in general, is that it has evolved in parallel with increasing levels of migration.

Simultaneously, according to official figures, migrant groups make a significant contribution to official crime rates across a range of offences. Specifically, although

\footnotetext{
*) The authors are indebted to Georgios Papanicolaou and Robert MacDonald for their valuable comments on earlier drafts of this paper.
} 
migrants constitute $6.4 \%$ of the total population of Greece, ${ }^{\mathrm{I}}$ according to official statistics published by the Ministry of Public Order (MPO), in 2005 they accounted for $27.6 \%$ of known offenders for theft/burglary, $24.9 \%$ of known offenders for vehicle theft, $24.2 \%$ of known offenders for animal theft, $33.8 \%$ of known offenders for robbery, $34 \%$ of known offenders for rape, and 31.8\% of known offenders for homicide. ${ }^{2}$ In addition, there has been a consistent over-representation of migrants in Greek prisons. For instance, in 2002 migrants constituted $45.9 \%$ of the total prison population in Greece, ${ }^{3}$ whereas in some prison facilities (e.g. in Patras), migrants constituted $60.5 \%$ of the population, and Albanians alone constituted $42.3 \%$ of all inmates on 30 May 200I. ${ }^{4}$ The disproportionate presence of migrants in the criminal justice system is probably typical of many European countries; however the case of Greece appears to be critical within the European context. ${ }^{5}$ Yet, the official criminal and prison statistics do not represent the reality of crime in the country and, indeed, other states due to a number of important limitations. ${ }^{6}$ Crucially, the police are hardly, as White puts it, "essentially passive respondents", 7 to a "migrant criminal population". Although the police are (apart from any court appearances) only involved in the initial stages of the process, police perceptions have a significant impact on the relationship between themselves and the migrant community in Greece, which in turn greatly affects the outcome of the case of a migrant offender/suspect and the subsequent production of crime and prison statistics. This in turn, again, can reinforce perceptions and possibly prejudices about the relationship of migrants to crime.

The research on migrants and crime in Greece, however, has been limited, and has not been equivalent to the "hyperbole associated with the debates surrounding

\footnotetext{
I) ESYE (200I), Census 200I: <www.statistics.gr>, accessed is March 2004.

2) MPO (2006), Statistics of Crime (First Six Months of 2006): <www.ydt.gr/main/Section. jsp?SectionID=I4337>, accessed I7 July 2006.

3) Ministry of Justice (2006), "Prison Statistics": <www.ministryofjustice.gr/modules.php?op=mo dload\&name=Sofronistiko\&file=page4 $>$, accessed i9 April 2007.
}

4) Patras Prison (200I), "Migrant inmates by country of origin, 3oth May 200I". Unpublished data.

5) See, for instance, M. Melossi, "In a Peaceful Life: Migration and the Crime of Modernity in Europe/Italy", s Punishment and Society, (2003), pp. 37I-397.

6) See G.A. Antonopoulos, "The Limitations of Official Statistics in Relation to the Criminality of Migrants in Greece", 6(3) Police Practice and Research, (2005), pp. 25I-260.

7) J. White, "Power/Knowledge and Public Space: Policing the Aboriginal Towns", 30 The Australian and New Zealand Journal of Criminology, (1997), 275-291, p. 275. 
... migrants". ${ }^{8}$ There is even less research focusing specifically on migrants and police perceptions and practices in the country and as a consequence there is no clear reference point for our findings. The purpose of this article is to provide an account of the perceptions of migration and migrants among a number of detectives in a large provincial city in Greece. The intention is to contribute to the limited existing Greek research and to a body of academic research and theory on migrants, crime and policing that is significantly Anglo-centric. Before proceeding, we provide an account of the Greek immigration context as well as an account of the methodology used in this study.

\section{The Greek Immigration Context}

Initially, for the sake of conceptual clarity, it should be mentioned that the term "migrants", which is typical of European categorizations, is used in the current study to refer to economic immigrants, political refugees, asylum seekers and immigrant ethnic Greeks because, despite the development of the above terms, it is extremely difficult to distinguish between those who are forced to migrate for political, religious or other reasons and those who migrate for purely economic reasons. ${ }^{9}$ Individuals from a number of geographical contexts are included in the category "migrants", specifically, the former Eastern bloc, Asia, Africa, and Latin America. Migrants from these contexts are included because, overwhelmingly, they are the ones around whom negative understandings of the "Other" coalesce.

Immigrant ethnic Greeks from Albania and some countries of the former Soviet Union are also included, for three reasons: a) because they face very serious difficulties integrating into Greek society, due to factors such as language problems, lack of educational qualifications, limited or erroneous information about the laws and functions of the Greek state, lack of job seeking skills and absent or limited social networking; ${ }^{\text {IO }}$ b) because negative stereotypes, attitudes and practices regarding these migrants exist among the Greek public, these being almost identical to those existing for non-ethnic Greek migrants; c) because, even if there were differences between immigrant ethnic Greeks and immigrants non-ethnic Greeks, due to inaccurate official statistics we are not in a position to distinguish between the two groups. Therefore, there are a number of nationalities/migrant groups that

8) R. King, G. Lazaridis, M. Koumandraki and N. Mai (200I), "Research Summary: Albanians in Italy and Greece: A Study in Migration Dynamics and Social Exclusion": <www.sussex.ac.uk/ migration/research/pdf/albania.pdf>, accessed 30 May 2004, p. I.

9) S. Gent, The Root Causes of Migration: Criticising the Approach and Finding a Way Forward, Sussex Migration Working Paper No. II (Brighton, 2002).

ı) I.N. Dimitrakopoulos, Racist Violence (Athens, 2002). 
share a range of fundamental problems, coupled with varying degrees of negative perceptions of their ethnicities and societies, and it is for these reasons that these groups are also referred to here.

On the other hand, the citizens of old EU countries are not included because, although technically they are migrants, in essence they are not, as they are citizens of EU member states. Moreover, the citizens of Iceland, Norway, Switzerland, Vatican City, USA, Canada, Australia, Malta, Monaco, Japan, Liechtenstein, and Cyprus are excluded because, although they are foreigners just as the citizens of EU member states, they are not considered to be migrants; they are not subjected to the social exclusionary policies, attitudes and practices that, for example, Eastern Europeans are subjected to. They are generally perceived as possessing positive traits, their ethnicities do not correspond to stereotypes of "cultural backwardness" and they are not associated with crime, as for instance, Eastern Europeans are.

It is extremely difficult to provide accurate figures regarding the number of migrants, as there is an unknown number of undocumented migrants in the country. However, we could provide the numbers and demographic characteristics of documented migrants, who have dramatically changed the Greek context since the early I990s. According to the last Greek Census in 200I, the total of documented migrants in Greece was 693,837 (6.4\% of the total population). ${ }^{\text {II }}$ The largest migrant group by far were Albanians, who constituted of $63.7 \%$ of the total documented migrant population, followed by Bulgarians, Georgians, Romanians, Russians, and Ukrainians. The rest of the migrant groups constituted of less than $2 \%$ of the total migrant population each, apart from the general group "Others", who are $6.3 \%$ of the migrant population. According to ESYE, the majority of documented migrants in Greece are male $(388,776)$. As far as the age distribution of migrants is concerned, more than half of the country's migrants are younger than thirty years old ( $51.7 \%)$, whereas the vast majority - 91\% - are below the age of forty-four. ${ }^{12}$

At the beginning of the 1990s, documented migrants in Greece were mainly employed in restaurants and hotels, with fewer numbers in the field of transportation and industry, ${ }^{13}$ whereas the biggest percentage of undocumented migrants were employed in seasonal agricultural or fishing work, or as cleaners and workers in the construction industry. ${ }^{14}$ They were paid less than half the wage of a Greek worker and, given that the employers did not pay social security contributions, and could hire and fire them whenever they wanted, the real cost may have been, as

\footnotetext{
II) ESYE (200I), op. cit.

12) ESYE (200I), op. cit.

13) X. Petrinioti, I Metanastefsi pros tin Ellada (Athens, 1993).

14) P. Linardos-Rylmon, Allodapoi Ergazomenoi ke Agora Ergasias stin Ellada (Athens, 1993).
} 
King et al. ${ }^{15}$ argue, as low as one quarter of the Greek rate. The latest Greek census (ESYE, 200I ${ }^{16}$ did not show any differences, in terms of employment sectors, between one migrant group and another, however, it did show differences in the patterns of employment of migrant groups. This census was also able to provide data as to the patterns of employment for male and female migrants. Specifically, male migrants are employed in construction and agriculture and fishing works, as well as industry, commerce, removals, mining, and tourism or as street vendors, whereas, the majority of female migrants are employed as domestic servants, babysitters, caretakers, and in agriculture. ${ }^{17}$

Migration, in political and scientific debates in Greece, has been approached as a social problem rather than a social phenomenon, ${ }^{18}$ and the positive contribution made by migrants to Greek society has been largely neglected. Migrants however, have contributed much in two spheres - demography and economics - which are, to a large extent, connected. The entrance of migrants, who are generally young, has mitigated the country's declining population, and has provided the workforce in vital sectors of the economy, such as agriculture, where labour shortfalls have not been filled by the Greek population. Finally, the migrant community in the country has kept inflation low, and is dynamic in terms of consumption and bank savings. ${ }^{19}$ Migrant participation in public life is almost absent; this is linked to a variety of factors, such as, insecure status of a number of immigrants, mistrust towards the Greek state and its agencies, and a lack of resources. ${ }^{20}$

\section{Previous International and Greek Research}

Research over the last 30 years or so (primarily in the Anglo-Saxon world) suggests widely held negative police attitudes and perceptions towards minority ethnic

I5) R. King, T. Iosifides \& L. Myrivili, “A Migrant's Story: From Albania to Athens”, 24 Journal of Ethnic and Migration Studies (1998) I59-175.

16) ESYE (200I), op. cit.

17) ESYE (200I), op. cit.

I8) A. Marvakis, D. Parsanoglou and M. Pavlou, "Metanastes stin Ellada: 'Provlimata', Koinonika Phenomena kai Ypokeimena”, in A. Marvakis, D. Parsanoglou and M. Pavlou (eds.), Metanastes stin Ellada (Athens, 200I) pp. 13-28.

19) A. Galanopoulos \& V. Dionysopoulou, “Ton Metanaston oi Koinotites”, Elefhterotypia (2003) 6 December.

20) R. Gropas \& A. Triandafyllidou (2005), "Migration in Greece at a Glance": <www.eliamep.gr/ eliamep/files/Migration\%20in\%20Greece_Oct\%202005\%20(2).pdf>, accessed 26 July 2006. 
groups, racial minorities, and migrants. ${ }^{21}$ In Britain, Cain (1973) ${ }^{22}$ showed that there are racist prejudices against black people who were perceived as prone to crime and/or violence and difficult to handle, whilst Asians were perceived to be liars, devious and potentially illegal immigrants. Later research came to verify that similar characterizations are commonplace in the police discourse and everyday practice. Smith and Gray (1985), ${ }^{23}$ for instance, found that negative and racist attitudes were accepted among the police, and a significant number of officers were also keen to support extreme right wing political parties sharing similar views. ${ }^{24}$ Smith and Gray (1985) ${ }^{25}$ argued that although racist banter/common was commonplace, it tended not to be translated into practice in police-minority encounters (though maybe knowing they were being watched by researchers influenced them). American research suggests similar patterns. As Hawkins and Thomas (I99I) note, the white police officers not only believed that black citizens were inferior to them but also that they were "more criminally inclined by nature than whites". ${ }^{26}$ In Australia, community consultations have revealed that the police perceive specific ethnic groups, such as the Italians, as heavily involved in organized crime, and young people from other minority ethnic groups as "delinquent", "a problem" and "troublemakers". ${ }^{27}$ There is also some research in continental Europe identifying racist attitudes towards minority ethnic groups on the part of police officers. ${ }^{28}$ Clearly, it is likely that negative stereotypical representations of

21) By "minority ethnic groups" we mean groups of people, who share cultural characteristics and consider themselves as a distinct group, whereas by "racial" minorities we mean groups of people who share inherited somatic characteristics such as skin colour. Most scientists have long considered the term "race" to have no scientific meaning and value at all (see P. van der Berghe, Race and Racism: A Comparative Perspective (2nd edn, New York, 1978); M.J. Bamshad and S.E. Olson, "Does Race Exist?", Scientific American, (2003) December, pp. 50-57; C. Webster, Understanding Race and Crime (Maidenhead, 2007); however, the term is used in this study because the United States collect information on "race". Although minority ethnic groups and migrants belong in different "jurisdictions", they constitute the "Others", who have been identified with danger, fear, and insecurity.

22) M. Cain, Society and the Policeman's Role (London, 1973).

23) D.J. Smith and J. Gray, Police and People in London: The PSI Report (Aldershot, 1985).

24) See R. Graef, Talking Blues: The Police in Their Own Words (London, 1989).

25) Smith and Gray (1985), op. cit.

26) H. Hawkins \& R. Thomas, "White Policing of Black Populations: A History of Race and Social Control in America”, in Cashmore, E. and McLaughlin, E. (eds.), Out of Order? Policing Black People (London, I991) 65-86, p. 75.

27) NSWEAC, 1992 cited in R.B.L. Chan, Changing Police Culture: Policing in a Multicultural Society (Cambridge, 1997), pp. 20-2I.

28) Bielefeld et al., 1982 cited in H-J. Albrecht, H-J. "Ethnic Minorities, Culture Conflicts and Crime", 24 Crime, Law and Social Change (1995) 19-36, p. 27. 
minority ethnic groups will have negative consequences in terms of police-minority relations. Wassermen (1996), ${ }^{29}$ for instance, discusses how, in 1995, white police officers in New York shot plain-clothed black police officers who at the time were attempting to arrest some robbers, because it was assumed that a black man with a gun was a robber.

As far as we are aware, the existing Greek research on police perceptions of migrants is limited to two studies: Papakonstantis (2000) ${ }^{30}$ and Vagena-Palaiologou (2006)..$^{\text {I }}$ It is worth looking into these two studies in more detail. In 1999, the Panteion University of Athens undertook research on police/migrants perception of each other within the context of the ODYSSEUS programme of the European Commission. The research was based on the analysis of questionnaires distributed to approximately 800 police officers and 2,500 documented and undocumented migrants. However, because this piece of research was based on questionnaires, it did not leave much space for the identification of attitudes towards migrants, and the only finding relevant to our study is in relation to responses to migration. According to Papakonstantis (2000), ${ }^{32}$ who participated in this study and provides an overview of some of the findings, the police officers thought criminality is the biggest problem in Greece (32.5\%), with unemployment (18.4\%) and "illegal" migration (17.I\%) next. Interestingly, the police officers' views on the ways "illegal" migration can be reduced were far more liberal than those of the migrants. Specifically, only $4 \%$ of the police officers that took part thought that the implementation of the Schengen agreement is a good measure against "illegal" migration, when the equivalent percentage for migrants was $84.8 \%$. (Though it could be argued that migrants do not have much information about the Schengen agreement).

In the second study by Vagena-Palaiologou (2006), ${ }^{33}$ it was found that $72.3 \%$ of the sample of police officers thought that migrants "contributed" to unemployment in Greece. The vast majority of the police (92.2\%) though that there has been an increase in criminality in the decade previous to the study, and which roughly coincides with the transformation of Greece to a popular destination country. Of these respondents, $57.5 \%$ and $35.9 \%$ said that foreigners were partly or exclusively to blame for this increase, respectively. Poverty and bad living conditions were

29) D. Wasserman, "Racial Generalisations and Police Discretion", in Kleining, J. (ed.), Handled With Discretion (Lanham, M.D, 1996) II5-I30.

30) G.B. Papakonstantis, "Astynomikoi kai Metanastes", Astynomiki Epitheorisi (2000) February, 86-90.

31) E. Vagena-Palaiologou, Ratsismos Ke Xenophobia: Erevna sti Dikaiosyni kai stin Astynomia (Athens, 2006).

32) Papakonstantis (2000), loc. cit.

33) Vagena-Palaiologou (2006), op. cit. 
considered as factors conducive to migrant criminality by $27.3 \%$ of the respondents, $21.8 \%$ suggested that migrants commit crime due to lack of respect for fellow humans, although $42.8 \%$ attributed migrant criminality to a mix of poverty, poor living conditions and lack of respect. Individual responses included the characterisation of migrant offenders as "born criminals" or "criminals by profession" ${ }^{34}$ In addition, only $2.9 \%$ considered migrants as "victims". Although, the majority $(86.4 \%)$ favoured treating migrants equally to Greeks, $13.6 \%$ suggested that migrant offenders should be treated more harshly by the criminal justice system or be deported. ${ }^{35}$

\section{Methodology}

The current project was conducted in 2002 in Patras, one of the largest Greek cities with a relatively large number of migrants from a variety of countries, though primarily Albania. Patras is also a transit point for Asian and African migrants heading to Western Europe. The participants were a snowball sample of male detectives $(n=26)$. We started with acquaintances working in the police and relied on referrals from these participants to generate additional participants. The advantages of this method of sampling are lowered search costs and an "informal" identification of participants. ${ }^{36}$ An additional benefit of this "multistage technique" 37 of sampling is the geographic proximity of the participants, a factor that helps to reduce administrative problems, especially in research contexts that require face-to-face contact - such as our interviews with the police. Semi-structured interviews were used as the basis for investigating police attitudes towards migration and migrants. All interviews apart from one were tape-recorded, however, on occasion, some participants who had originally agreed to the interview being recorded requested that the tape be turned off. In order to preserve the good relationship with interviewees such a request was, of course, complied with.

It is recognized that our study possesses a number of limitations. Firstly, there are disadvantages associated with snowball sampling. There may have been gatekeeper bias, whereby initial participants referred us to additional participants holding largely similar or, even virtually identical viewpoints. Secondly, the study

\footnotetext{
34) Vagena-Palaiologou (2006), op. cit.

35) Vagena-Palaiologou (2006), loc. cit.

36) R. Atkinson and J. Flint (200I), "Accessing Hidden and Hard-to-Reach Populations: Snowball Research Strategies”, 33 Social Research Update (200I): <www.soc.surrey.ac.uk/sru/SRU33.html>, accessed in April 2005

37) C. Lawrence Neuman, Social Research Methods: Qualitative and Quantitative Approaches (5th edn, Boston, 2003)
} 
focuses on a geographically limited area of Greece. Although we strongly suspect that similar trends in beliefs and practices in relation to migrants and crime exist in other localities in Greece, due to the "historical tendency of Greek policing ...toward increased centralisation", ${ }^{38}$ we were not able to investigate the issues throughout the whole country.

\section{Police Perception of Migration in Greece}

There were wide variations from one detective to another when it came to estimating the number of migrants currently residing in Greece. These estimates ranged from 500,000 to $2,000,000$. The lack of knowledge regarding migrant numbers results primarily from the unknown number of undocumented migrants entering (and residing in) Greece. The quality of the contact the detectives had with migrants, something that plays an important role in their attitudes towards the migrants, was rather negative, and one of the reasons for this is that, as van Maanen ${ }^{39}$ suggests, “... such encounters are strained interpersonally ...”. Similar findings can be viewed at Pitkänen and Kouki's (2002) ${ }^{40}$ study in which a large proportion of their Finnish police participants characterized their experiences with migrants in the country as "negative".

The detectives recognized the "push", "pull" and facilitating factors influencing the phenomenon of migration into the country. In general terms, the detectives did not consider migration to be a positive phenomenon for Greek society, but rather as a "huge problem" that is getting worse. Most of the detectives referred to migration as a "plague" for the country. Migration to Greece was not only considered as a problem in itself, but also as a major cause of many other problems that affected the quality of life in Greek society -criminality, insecurity and unemployment were often referred to. The mentality and general tenor of the detectives' responses are clearly reflected in the following response:

Migration has harmed Greece to a very large extent. Migrants have made us fearful of sleeping in our yards and balconies in the summer, as we used to do before. Everyone lives in fear now.

38) G. S. Rigakos \& G. Papanicolaou, "The Political Economy of Greek Policing: Between NeoLiberalism and the Sovereign State", I3(3) Policing and Society, (2003) 27I-304, p. 301.

39) J. van Maanen, "Kinsmen in Repose: Occupational Perspectives of Patrolmen", in Manning, P. K. and van Maanen, J. (eds.), Policing: A View from the Street (Santa Monica, Ca., 1978) II5-I28, p. I25.

40) P. Pitkänen and S. Kouki, "Meeting Foreign Cultures: A Survey of the Attitudes of Finnish Authorities Towards Immigrants and Immigration", 28(I) Journal of Ethnic and Migration Studies 
Foreigners take jobs from the Greeks. Greece has become a "fenceless vineyard" $4 \mathrm{I}$ in which anyone can enter whenever they want, and the results are evident. They made us install alarms in our houses and sleep with a gun under the pillow. I do not think that migrants are a good thing for Greece. (Interview 2I: 2-3).

Apart from criminality, insecurity and unemployment the detectives provided further interesting examples of the "problems" migration and migrants have had on the country. One example was a purported imbalance between Greeks and migrants in certain sectors of the economy, such as agriculture and construction, and the effect of the migrants' presence in the regulation of the Greek workers' monthly income. Specifically, the argument was that the Greek unskilled workers' monthly income has remained the same over the last ten years. This argument is rather weak since the migrants' effects on the Greek economy and levels of employment are generally positive. ${ }^{42}$ Contrary to what the vast majority of the Greek public believes, migrants generally do not displace Greek workers from the labour market as they tend to be employed in jobs that require unskilled labour. ${ }^{43}$ The sector in which there may be a displacement of Greek workers by migrants is the construction industry. However, in general terms, as Ioakeimoglou (200I) ${ }^{44}$ suggests, migrant workers create two jobs for Greeks for every displacement of a Greek worker. In addition, in Greece migrant labour provides enormous benefits for the (capitalist) economy. Apart from anything else, it does this because it's a supply of cheap labour and has a knock-on effect of depressing wages at least in certain sectors. In Greece many employers, including some of the detectives interviewed who owned olive fields, recruited (undocumented) migrants as they were are able to pay below the minimum wage.

According to the detectives, migrants also pose problems relating to issues of national security. The majority of the detectives made the point that in many villages the population of migrants is higher than that of Greeks, which, in their view, had created a very dangerous situation.

4I) The phrase "fenceless vineyard" is metaphorically used by the Greek people to refer to a situation conducive to lawlessness and disorder. This phrase is sentimentally much more "charged" in Greek than its English translation.

42) A. Lymberaki and T. Pelagidis, O "Fovos tou Ksenou" stin Agora Ergasias: Anohes kai Prokatalipseis stin Anaptyksi (Athens, 2000).

43) See Lymberaki and Pelagidis (2000), op. cit.

44) E. Ioakeimoglou, "Oi Metanastes kai I Apascholisi”, in Marvakis, A., Parsanoglou, D. and Pavlou, M. (eds.), Metanastes stin Ellada (Athens, 200I) 8I-94. 
In a few years they may say that they are 2,000,000 Muslims and they want mosques. Imagine if that happens... (Interview 7: 5).

Similar concerns and sentiments have been expressed by other important officials and politicians related in one way or another to the police. An article by a retired high-ranking police officer in the Hellenic Police Review, provides a characteristic example. In the article the author suggests that migrants can cause the "ghettoization" of some areas, especially in large cities, and can create "dangerous minorities within Greek soil”. ${ }^{45}$ Moreover, the Greek ministers of public order from 1993 to 1996 argued that undocumented migrants from Iraq and Pakistan "have been settling in the area of Thrace on the Greece/Turkey border". ${ }^{6}$ This is described by the ministers as a "sensitive" area, due to the number of Greek Muslims living there. Such xenophobic discourses, which generally serve to offer reassurance and affirmation of national identity "when the nationalistic self-images run into crisis", 47 have appeared within the context of a shift in Greek society from homogeneity to heterogeneity over the past fifteen years. The large-scale migration of the I990s has led to, in the words of Christopoulos (200I) $4^{8}$ "the end of national homogeneity". A similar development has occurred in many other countries. In Denmark, for example, despite the fact that Danish citizens had a very good reputation for "tolerance", when the country was transformed into a heterogeneous one, attitudes towards migrants worsened. ${ }^{49}$ It is important to note, however, that despite the fact that Greece has only experienced significant waves of immigration since the early I990s, concerns based upon such notions as endangered "purity" and the "Greekness" of Greece are not new. Tzanelli (2002) ${ }^{50}$ informs us of similar widespread official and press debates about the "Other" "polluting" Greek culture in the igth century. Greek anxieties about "Greekness" has been constantly played out over

45) A. Theofilopoulos, "Lathrometanastes: Epiptoseis stin Asfaleia kai Oikonomiki-Koinoniki Zoi tis Horas", Astynomiki Epitheorisi (1999) November, 696-698, p. 697.

46) V. Karydis, I Eglimatikotita ton Metanaston stin Ellada: Zitimata Theorias kai Anteglimatikis Politikis (Athens, 1996).

47) A. Wimmer, "Explaining Xenophobia and Racism: A Critical Review of Current Research Approaches", 20(I) Ethnic and Racial Studies (1997) I7-4I, p. I7.

48) D. Christopoulos, “To Telos tis Ethnikis Omo(io)geneias: Paradosiakes kai Nees Morfes Eterotitas stin Ellada”, in Marvakis, A., Parsanoglou, D. and Pavlou, M. (eds.), Metanastes stin Ellada (Athens, 200I) $57-80$, p. 57 .

49) Y. Enoch, "The Intolerance of a Tolerant People: Ethnic Relations in Denmark", I7(2) Ethnic and Racial Studies (1994) 282-300.

so) R. Tzanelli, "Haunted by the 'Enemy' Within: Brigandage, Vlachian/Albanian Greekness, Turkish 'Contamination' and Narratives of Greek Nationhood in the Dilessi/Marathon Affair (I870)", 20(I) Journal of Modern Greek Studies (2002) 47-74. 
some considerable time in relation to claims and counter-claims over borders and boundaries of territorial integrity and Greek ethnicity in relation to for example, Turkey and the former Yugoslavia. Consequently, there is a hyper-sensitivity about who "belongs" and who does not.

Negative perceptions of migration in Greece within the police institution can be partly attributed to the fact that police work is concerned with maintaining the status quo, hence the "... police represent conventional authority". 5I The detectives interviewed, viewed migration through the prism of a "social problem" means that it is viewed as "being threatening to the very structures of the society that produces them, the antithesis of structure and order". ${ }^{2}$ The sudden influx of large numbers of migrants into the country in the early nineties was, regardless of subsequent social and economic developments, a factor that, in itself had influenced the perceptions of the detectives interviewed. Up to that point, Greece was one of the most homogeneous countries of the world; ; $^{33}$ it was also a country from which people had traditionally emigrated. All of the detectives put forward "solutions" to what they saw as the problems caused by migration in Greece, though there was no consensus regarding the nature of these "solutions". Broadly speaking, however, their responses can be categorized as either "hard" or "soft" (an equivalent distinction was made by Grönfors, ${ }_{19} 8 \mathrm{I},{ }^{54}$ in his study of the relationship between police and Gypsies in Finland, and it is from this study that we borrow the terms "softliners" and "hardliners"). The "softliners" ( $\mathrm{n}=\mathrm{I} 2)$ argued in favour of the social, linguistic, educational etc. integration of migrants into Greek society, together with periodic regularization of the number of migrants allowed to enter the country in accordance with the needs of the labour market. The "hardliners" $(\mathrm{n}=\mathrm{I} 4)$ suggested more intense policing, a stricter legal framework to control inward migration, including a reduction in the quotas, the (practical) implementation of the 200I agreement with Turkey on the refoulement (epanaproothisi) of migrants, and deportation. Responses from "hardliners" included comments along the lines of "They should go home" (e.g. interview 2r: 4). The hardliners also placed a great emphasis on (and in fact elaborated on) the registration of all migrants into lists (one for each prefecture), and argued that migrants should not be able to move out of the prefecture in which they are registered. This "solution", which clearly constitutes an infringement of the section 5 of the Greek Constitution, stems out of the

s1) J.R. Lambert, Crime, Police and Race Relations: A Study in Birmingham (London, 1970), p. I98.

52) M. Grönfors, "Police Perception of Social Problems and Clients: The Case of the Gypsies in Finland", 9 International Journal of the Sociology of Law (I98I) 345-359, p. 353.

53) National Geographic Society, "The Balkans/Refugees: Double Map Supplement", National Geographic, (2000) February.

54) Grönfors (I98I), op. cit., p. 353. 
detectives' experience of migrants who had committed a crime providing the police with false names and other information in the various places they moved to, and in consequence making tracking their movements extremely difficult. Moreover, a number of detectives suggested that "assimilation" (as opposed to "integration" suggested by the "softliners") would be a solution to the problems they identified: "We are interested in the migrant being a real Greek" (interview 7: 6).

For these detectives, the assimilation of migrants into a supposed superior Greek culture, a view originating from the ideals of ancient Greece, would make them better individuals. This is clearly a racist argument, since it is based on an unshaken belief that different ethnic or what are perceived to be "racial" groups are comprised of "individuals (who) are classified as inferior/superior in terms of ... cultural worth ...". 55 There was a strong sense of "us" and "them" evident in the discourse of the detectives, and this is also present in the public's accounts. ${ }^{56}$ As Wimmer (1997) ${ }^{57}$ would argue, this represents a Manichean view rooted in the notion of a superior (Greek) culture locked in conflict with a barbaric (migrant) culture. In relation to this, it is interesting to note that the screensaver on one of the interviewee's mobile phone included a Greek flag and the ancient Greek moto "pas mi Ellin, varvaros" ("Anyone who is not Greek, is a barbarian"). Migrants are "symbolically excluded from the pale of "civilisation". ${ }^{8}$ Simultaneously, these pejorative categorizations symbolize Greek self-perceptions, not simply as "European", but also as "European par excellance". 59 In this context we can note that in the Second Report for the European Monitoring Centre on Racism and Xenophobia, Greece was identified as the nation most resistant to multiculturalism when compared with other members of the European Union. ${ }^{60}$

55) J. Tierney, "Race, Colonialism and Migration", in Tierney, J. (ed.), Race, Migration and Schooling (London, I982) I-43, p. 24.

56) G.A. Antonopoulos, "Public Reporting of Criminal Activities to the Police in Greece: Is There a Difference When the Offender is Migrant?", I4(2) European Journal of Crime, Criminal Law and Criminal Justice (2006) I35-I60.

57) A. Wimmer, "Explaining Xenophobia and Racism: A Critical Review of Current Research Approaches", 20(I) Ethnic and Racial Studies (1997) 17-4I.

58) R. Tzanelli, "Not My Flag! Citizenship and Nationhood in the Margins of Europe (Greece, October 2000/2003)", 29(I) Ethnic and Racial Studies (2006) 27-49, p. 42.

59) Tzanelli (2006), op. cit., p. 42.

6o) M. Coenders, M. Lubbers \& P. Scheepers, Majorities' Attitudes Towards Minorities in European Union Member States: Results from the Standard Eurobarometers 1997-2000-2003, Report 2 for the European Monitoring Centre on Racism and Xenophobia (Nijmegen, 2003). 


\section{Police Perception of Migrants}

Although the detectives considered migration and migrants as a problem, an assumption that all encounters between the police and every migrant group is "inevitably conflict-based is simplistic". ${ }^{61}$ It is true that research has indicated that the police tend to think in "rigid categories" 62 and have specific attitudes towards female colleagues, female offenders, ${ }^{63}$ homosexuals, ${ }^{64}$ and minority ethnic groups. Stereotypes are functional to police work. ${ }^{65}$ An integral part of police subculture is mission of the police as a "thin blue line" between order and chaos. ${ }^{66}$ The practical use of these stereotypes is that they help to create an ordered world out of potential chaos.

However, the detectives interviewed had different views about the different migrant groups present in Greece. Although having the status of migrant was enough of a signifier for the police, this was not the only criterion for the detectives to have a negative image of migrants, as some groups such as Indians, Polish, Serbs, Kurds, Filipinos, Iraqis, Pakistanis, Bangladeshis, and Africans were generally valued positively. Epithets such as "cultured", "gentle", "hard-working", "law-abiding", "saints", etc., are indicative of this evaluation. It is also important to note that no racial (as opposed to ethnic) prejudice appeared as Asians and Africans were generally evaluated positively. There were also groups that were evaluated in a neutral fashion. Russians, for example, were generally perceived as "disciplined". However, the detectives suggested that it would be extremely dangerous if someone "messed with cliques of Russians involved in organized criminal activities". The groups that were exclusively valued negatively were the Albanians and the Romanians. The Albanians, in particular, apart from the recognition on the part of the detectives that they are "hard-working", were considered "dangerous", "criminals", "thieves", "murderers", "rapists". What is apparent is that, in contrast to the "qualities" of the other migrant groups in the country, the qualities of the Albanians, as perceived by the detectives, are crime-related. Albanians are viewed as being inherently crimi-

6I) N. J. Britton, “Examining Police/Black Relations: What's in a Story?”, 23(4) Ethnic and Racial Studies (2000) 692-7II, p. 694.

62) R.W.Balch, "The Police Personality: Fact of Fiction", 63 The Journal of Criminal Law, Criminology and Police Science (1972) I06-II9, p. I07.

63) R. Horn, "Not Real Criminals: Police Perceptions of Women Offenders", I9 Criminal Justice Matters (I995) I7-I8.

64) M. Burke, "Homosexuality as Deviance: The Case of the Gay Police Officer", 34(2) The British Journal of Criminology (1994) I92-203.

65) R. Reiner, The Politics of the Police (2nd edn, Hemel Hempstead, 1992).

66) J.H. Skolnick. \& J.J. Fyfe, Above the Law: Police and the Excessive Use of Force (New York, 1993). 
nal and violent, and characterizations such as "thieves by birth", "cold-blooded", "killers by instinct", and "born criminals" saturate the detectives' perception of the Albanian migrants. Danger, as well as risk in general are constructs of police work that are "sustained by police officers in the course of their routine work", ${ }^{67}$ and is part of the threat-danger nexus that Manning (1977) ${ }^{68}$ has talked about. It is worth noting that the Albanians are also the "dangerousness reference point" when it comes to the evaluation of the Romanians and the Polish (see Table I).

One characterization of Albanian migrants, and voiced by the detectives, that is particularly negative is that of "animal", a metaphor that can function to support

Table I. Epithets and Characterisations of Migrants by the Detectives, by Group

\begin{tabular}{|c|c|}
\hline Groups & Epithets/Characterisations \\
\hline Albanians & 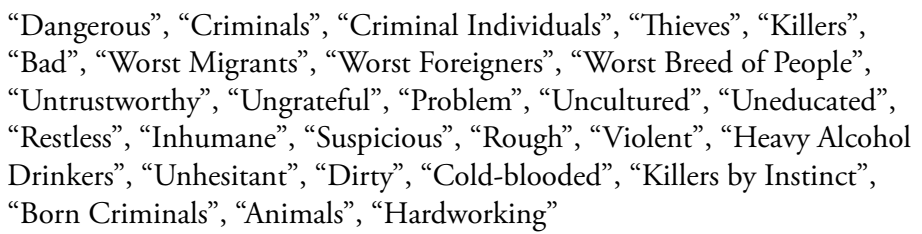 \\
\hline Romanians & "Thieves", "Less Dangerous than the Albanians", "Burglars" \\
\hline Polish & $\begin{array}{l}\text { "Great People”, "Hardworking”, "Gentle”, "Clean”, "Quiet”, "Disciplined”, } \\
\text { "Polish are not ... Albanians" }\end{array}$ \\
\hline Bulgarians & "Disciplined" \\
\hline Russians & "Disciplined", "Mafiosi" \\
\hline Indians & $\begin{array}{l}\text { "Example of Migrants", “Saints”, “Quiet”, "Hardworking”, "Gentle”, } \\
\text { "Cultured" }\end{array}$ \\
\hline Phillipinos & "Hardworking", "Disciplined" \\
\hline Kurds & "Unfortunate”, "Wretched”, “Good”, "Quiet”, "Lazy” \\
\hline Iraqi & "Unfortunate", "Quiet" \\
\hline Serbs & "Very Good People" \\
\hline Pakistani & "Quiet" \\
\hline Bangladeshi & "Quiet" \\
\hline Africans & $\begin{array}{l}\text { "Friendly", "Hardworking”, “Clean”, “Good”, “Good Guys”, } \\
\text { "Disciplined", "Quiet”, "Law-abiding” }\end{array}$ \\
\hline
\end{tabular}

67) S. Holdaway, Inside the British Police (Oxford, 1983), p. I9.

68) P.K. Manning, Police Work (Cambridge, Mass., 1977). 
the detectives' perception of themselves as "fully human". ${ }^{69}$ The narrations of the detectives regarding the physical endurance of the Albanians unlawfully crossing the borders, have a played an important role in the stereotyping of this migrant group. As noted by King et al. ${ }^{70}$ because the border police (and the army) very often fail to apprehend undocumented migrants when chasing them in the rough, mountainous terrain of the Greek-Albanian borders, they use the myth of the "Albanian superhuman". This, though, does not use the American comic book hero as a reference point, rather, the animal-like qualities associated with "atavism" - an evolutionary throwback - found in Lombroso's theory. ${ }^{71}$ Below is one narration that clearly reinforces King et al.'s (1998) ${ }^{72}$ account of "animal analogy": ${ }^{73}$

One day, when I was going home after work, I came across two young Albanians who looked suspicious. I called them and they came up close to me. When I asked them whether they had papers they started running and, although I chased them for a few metres, they disappeared. Have you ever seen an Albanian running ...? (Interview I: 9).

In this case, the attempt of the detective to arrest the Albanian migrants was based on their looking suspicious, a situation, however, that leaves much space for "particularistic law enforcement or, simply, discretion". ${ }^{74}$ The extent to which the suspiciousness of the Albanian migrants in these cases was embodied in objective features is unknown. However, it should be mentioned that it may be the case that stereotypes of likely offenders are a self-fulfilling prophecy as the Albanians are disproportionally stopped and searched, questioned and arrested, a process that inevitably leads to the amplification of deviance and crime of the particular migrant groups. ${ }^{75}$

69) Lévi-Strauss, 1966 cited by M. Young, An Inside Job: Policing and Police Culture in Britain (Oxford, I99I), p. II2.

70) King et al. (1998), op. cit.

71) See, for instance, J. Tierney, Criminology: Theory and Context (2nd edn, Harlow, 2006).

72) King et al. (1998), op. cit.

73) B. Bowling, C. Phillips, A. Campbell and M. Docking (200I), Policing and Human Rights: Eliminating Discrimination, Xenophobia, Intolerance, and the Abuse of Power from Policework (abstract): $<$ www.unrisd.org>, accessed 8 July 2004.

74) D. J. Black, “The Mobilization of Law”, in Manning, P. K. and van Maanen, J. (eds.), Policing: $A$ View from the Street (Santa Monica, Ca., 1978) I67-I87, p. I84.

75) J. Young, "The Role of the Police as Amplifiers of Deviancy, Negotiators of Reality, and Translators of Fantasy: Some Consequences of Our Present System of Drug Control as Seen in Notting Hill”, in Cohen, S. (ed.), Images of Deviance (Harmondsworth, I97I) 27-6I; see also J. Lea, "Police Racism: Some Theories and Their Policy Implications", in Matthews, R. and Young, J. (eds.), Confronting Crime (London, 1986) I45-165. 
Apart from Albanian migrants, a few detectives spoke of unpleasant experiences with Kurdish migrants. However, in recounting these experiences it was clear that police perceptions of "Others" are contingent upon already existing attitudes and assumptions about different nationalities. In effect, police understandings and practices are predicated upon a sort of "pecking order". For example, after the arrest of Abdullah Oçalan, the leader of the Kurdish Workers' Party (PKK), by the Turkish secret services in Kenya, there was a huge disappointment among the Kurdish people in Greece (and across the rest of Europe), and a widespread belief that the Greek government was partly, if not exclusively, responsible. There were small-scale riots in large cities, and inevitable clashes with the police. In one of these clashes, one detective had a large, plastic garbage bucket thrown at his head. The detective, however, did not judge the Kurdish people by this incident; on the contrary he had a very good view of them. There is probably one more reasons why the police have better relationships with the Kurds: The detectives believed that the Kurds, unlike Albanians, are political refugees whose primary aim is to move as soon as possible from Greece to other Western European countries. In other words, the Kurds were not seen as a threat to the homogeneity of Greece; Greece is merely a staging post. Thus attitudes and perceptions are not only a function of specific experiences with groups of people. Importantly, they are the product of the interaction between personal experience and "the accumulated folk wisdom of community experiences". ${ }^{76}$

\section{Police Perception of the Realationship between Migrants and Crime in Greece}

As shown earlier, criminality (along with insecurity and unemployment) was perceived as the greatest problem caused by the presence of migrants in the country. The detectives had absolutely no doubt that criminality in Greece had increased since the beginning of the I990s, and in fact further increases were predicted:

We were a country of Io,000,0oo people with an X number of offenders and to this a Y number of offenders from other countries was added. (Interview I: II).

This is in accordance with Tsalikoglou et al.'s77 survey and Vagena-Palaiologou's

76) T. Jefferson, "The Racism of Criminalisation: Policing and the Reproduction of the Criminal Other", in Gelsthorpe, L. (ed.), Minority Ethnic Groups in the Criminal Justice System (Cambridge, 1993) 26-46, p. 38 .

77) As cited by V. Karydis, "Criminality or Criminalisation of Migrants in Greece? An Attempt at Synthesis”, in Ruggiero, V., South, N. and Taylor, I. (eds.), The New Criminology: Crime and Social Order in Europe (London, 1998) 350-367, p. 353. 
study, ${ }^{78}$ which showed that percentages of police of all ranks in their samples thought that the increase in crime rates in Greece was attributable to migrants. In our study the detectives were confident enough to provide estimates of the increase in criminality since the beginning of the 1990 - these varied between an "optimistic" doubling and a "pessimistic" quadrupling. Their confidence did not derive from detailed knowledge of crime statistics, rather, it based simply on the fact that the Greek prison population included a disproportionate number of migrants. The most interesting finding in terms of the relationship between migrants and crime in Greece, however, was the detectives' belief that migrants also indirectly caused an increase in criminality among Greeks. The logic of this argument was based upon the view that an unknown number of Greeks where using the presence of (criminalized) Albanians to, in effect, cover their tracks:

From the moment the migrants and especially the Albanians came into Greece, the Greeks commit more crimes. Before the Greeks commit a robbery or a burglary they think: "there are a lot of Albanians in this area, so the people will say that they did it". And in this way they commit a crime that they would not otherwise commit (Interview 2I: 5).

The detectives' extremely negative view of Albanians, which involved identifying them with "danger", theft, violence and insecurity, rendered the interviewer's intention to ask them which migrant group is primarily responsible for the increase in criminality in Greece redundant. Apart from the Albanians, the other three groups that are heavily involved in criminal activities in the country are, according to the detectives, the Romanians, the Russians and the Turks. Bulgarians, Serbs, Kurds and Iraqis were also mentioned, but to a much lesser, almost minimal extent. As far as the detectives were concerned, when compared with Albanians, the criminal activities of all of these groups are minor. In fact, for the police, the issue of the relationship between migrants and crime is primarily an issue of the relationship between Albanians and crime. Worth noting is that the difference between the Albanians and the other groups was perceived of as quantitative as well as qualitative. Albanians, according to the detectives, are involved in thefts, murders, robberies, rapes, burglaries, drug trafficking, thefts of vehicles that would later be sent in parts, either to Albania or to other countries, prostitution-related offences, migrant smuggling and virtually every criminal activity they have the opportunity to get involved in. Interestingly, the police had also been confronted with a number of Albanian family violence incidents the number of which "exceeds that of the Greek population". However, the detectives tended to view these incidents from the perspective of the offender, rather than the victim. This is not an exceptional 
tendency. As Pearson et al. ${ }^{79}$ have noted, the British police in the 1980 os not only rejected the view that racist violence was a serious social problem, but also emphasised intra-racial victimisation, thus focusing again on the criminality of minority ethnic groups. The detectives argued that the characteristic element of many of the crimes committed by Albanians is extreme violence. From this perspective, the motives for acts of violence are personal disputes that had their roots in Albania. Given that Albanians are believed to commit more violent crime, crime resulting in death and forcible sex offences, the police devote a larger number of detectives, time and other resources to these crimes. Romanians, according to the detectives, are involved in thefts, burglaries and prostitution-related offences, whereas in the case of Russians it is thefts, money laundering, "death contracts" and drug trafficking. Bulgarians and Serbs are primarily involved in thefts, Kurds and Iraqis in the smuggling of migrants, and Turks in the smuggling of migrants and drug trafficking. Whether the detectives' perception of the involvement of migrants reflects their actual involvement in crime is of course, not known.

An important dimension to the detectives' perception of Albanian criminality is that it is committed by the majority of Albanian migrants, and young Albanians in general are seen as criminals. However, criminality among other migrant groups is associated with only small segments of these groups. This finding is congruent with Lea's (1986) analysis of police understandings of black criminality in Britain: "While the police may be quite precise about what sub-groups of the white population they regard as being involved in particular types of crime, they may be far less precise in the case of the blacks seeing them involved in crime as a racial group" ${ }^{80}$

The idea that the increase in criminality, as well as the qualitative transformation of criminality, is exclusively caused by migrants, may partly be a result of an agenda oriented towards securing a positive image vis a vis the Greek community from which they are drawn, rather than from the Albanian community they are policing. The view that the police in Greece, and especially "the leadership of the police are happy with the situation, since the low detection rates can be explained in terms of the criminal activity of the migrants" ${ }^{8 \mathrm{I}}$ is untenable, since an inexorably rising crime rate would undermine both police effectiveness and the relationship between the police and the (Greek) public. "Prioritizing" criminal activities of a violent nature would explain the police focus on Albanian criminality; however, it

79) G. Pearson, A. Sampson, H. Blagg, P. Stubbs and D. Smith, "Policing Racism", in Morgan, R. and Smith, D.J. (eds.), Coming to Terms with Policing: Perspectives on Policy (London, I989) II8-I37.

8o) Lea (1986), op. cit., p. I63.

8I) Karydis (1998), op. cit., p. 353. 
may be the case that, in reality, they focus on Albanians because they think they will have a better result when it comes to violent offences. In other words, by shifting "from suspecting individuals to suspecting social categories" 82 the detectives may discriminate statistically without having any intention of discriminating directly against the Albanians and, in effect, only focusing on the rewards offered by this kind of "discrimination". ${ }^{83}$

Finally, as is apparent from the absence of any accounts of the victimisation of migrants, the police refuse to view migrants as victims of a crime. The police perception of the relationship between migrants and crime is, in essence, based upon a perception of migrants as offenders, a perception that not only neglects the needs of the migrant community but also contributes much to the consolidation of the migrant-criminal stereotype, and adds to the vulnerability of migrant groups.

\section{Discussion-Conclusion-Recommendations}

The police are an important piece of the migrants-crime-and-criminal justice jigsaw. In respect to their relationship with (minorities and) migrants, this study identifies with the Anglo-Saxon research and part of the existing Greek research, in that it shows that there are high levels of prejudice among the Greek police. However, explanations for why this happens are much less clear. What is important to note is that although the findings are based on a locality in Greece, the findings are nationally and globally relevant.

Our findings have to be viewed within the wider immigration social control in Greece. Since 1991, when the Law on Aliens (L. 1975/199I) was introduced, migration has been identified as a national security issue, and migrants have been criminalised and excluded. Following pieces of legislation, such as the Law on Aliens 2910/200I, although should be credited with providing some rights to the migrants it still encouraged the identification of migration with a public order and national security issue. The legal framework in Greece, especially within the first ten years when the country was transformed into a country of immigration, influenced "the opportunity structure of undocumented migrants". ${ }^{4}$ The rigid

82) J. Young, "From Inclusive to Exclusive Society: Nightmares in the European Dream", in Ruggiero, V., South, N. and Taylor, I. (eds.), The New European Criminology: Crime and Social Order in Europe (London, 1998) 64-91, p. 76.

83) See M. Banton, "Categorical and Statistical Discrimination”, 6(3) Ethnic and Racial Studies (1983) 267-283.

84) G. Engbersen and J. van der Leun, "Illegality and Criminality: The Differential Opportunity Structure of Undocumented Immigrants", in Koser, K. and Lutz, H. (eds.), The New Migration in Europe: Social Constructions and Social Realities (New York, 1998) 199-223, p. 217. 
migration framework in Greece and the securitisation of irregular migration in the country is embodied to the low number of asylum applications and the small percentage of successful applications ${ }^{85}$ as well as the high numbers of migrants deported from Greece. For example, it is estimated that from I99I until the first half of I999, I,820,000 migrants were deported, of which I,700,000 were from Albania. ${ }^{86}$

The public attitude towards migrants is generally unfavourable. Recently, Antonopoulos found widespread stereotypical public views about migrants. Specifically, he found that his participants would refer to migrants "with several derogatory terms such as, for example, dirty-migrants and dirty-Albanians, or they would refer to them by using specific words that show the criminal stereotype of the migrants such as criminals, and thieves" ${ }^{87} \mathrm{He}$ also found that these perceptions are the root of a tendency among the Greek public to report to the police criminal activities committed by migrants more readily than criminal activities committed by Greeks. ${ }^{88}$ A "moral panic" about (the criminality of) migrants has been prevalent in Greece, and the media representations of migrants on the national and local level, which amplify the criminal migrant stereotype, have contributed to this to a very large extent. ${ }^{89}$ During the 1990 media reported on "waves" of migrant criminality attributed primarily to Albanian migrants, embellishing these reports with representations such as "criminal", "dangerous", "mafiosi"..$^{90}$

Although, as mentioned before, explanations as to the high levels of police prejudice towards migrants are less clear. There are a number of reasons why these attitudes are present, which may be similar or identical to those present in

A new immigration law was adopted by the Greek parliament in 2005, the Law 3386/2005 with the objectives of coordinating the country's immigration policy and harmonizing it with EU legislation and regulations, simplifying procedures, providing social inclusion policies, addressing the status of human trafficking victims etc. This immigration law, which was put into effect on January I, 2006 (and amended in January 2007) has been criticized -among other - for ignoring the undocumented migrants residing in Greece (see Gropas and Triandafyllidou (2005), op. cit.).

85) See, for instance, G.A. Antonopoulos, "The Legal Framework of Migration in Greece I99I-200I and Its Effects”, 20(I\&2) International Review of Law, Computers and Technology (2006) 135-I47.

86) Theofilopoulos (1999), op. cit.

87) G.A. Antonopoulos, "Public Reporting of Criminal Activities to the Police in Greece: Is There a Difference When the Offender is Migrant?" I4(2) European Journal of Crime, Criminal Law and Criminal Justice (2006) I35-I60, p. I50; see also Karydis (1998), op. cit.

88) Antonopoulos (2006), op. cit.

89) See Karydis (1996), op. cit.; Konstantinidou (200I) op. cit.; M. Pavlou, "Oi Lathremporoi tou Fovou: Ratsistikos Logos kai Metanastes ston Typo Mias Ypopsifias Mitropolis”, in Marvakis, A., Parsanoglou, D. and Pavlou, M. (eds.), Metanastes stin Ellada (Athens, 200I) I27-I62.

90) Konstantinidou (200I), op. cit. 
the social consciousness of the Greek public in general. ${ }^{\text {II }}$ If the police are a crosssection of the population ${ }^{92}$ then it is not surprising for these to be present in the social consciousness of the police. ${ }^{93}$ Firstly, Greece is an inexperienced country in immigration although the country is very experienced in emigration. This is also reflected on the fact that research on migrants, crime and the criminal justice system in Greece is in an embryonic stage. The large (for Greece) numbers of immigrants meant that the myth of the national, religious, and linguistic homogeneity of Greece was now exposed. ${ }^{94}$ Ethnic stereotypes are more likely to develop in those societies which are ethnically and culturally heterogeneous societies in which several impediments to inter-ethnic group communication exist. ${ }^{95}$ As it was shown there is a tendency among the detectives interviewed to differentiate among "Us" the Greeks and "Them" the migrants, a practice that re-defines the Greek national identity. ${ }^{96}$ The persons in the out-group (migrant group) are viewed negatively and as a homogeneous group possessing negative traits. ${ }^{97}$ Although there are differences in the detectives' qualitative evaluation of migrants, the migrants as one group are generally identified with a series of negative traits. Very importantly, the "criminal other" has been dealt with as a "master status" 98 in Greece.

The negative attitudes towards the Albanian migrants in particular can be explained by three additional factors. Firstly, the size of the Albanian migrants' presence in the total migrant population in Greece. As we showed earlier, the numbers of documented migrants in the country, Albanians account for $63.7 \%$ of the migrant population, with Bulgarians in second place, far outdistanced with 5.4\%. ${ }^{99}$ Therefore, it has been Albanian migration that intensified migration into Greece in general, and it is the particular ethnic group that made Greeks to broadly perceive immigration for the first time, and associate it with "backwardness" of

\footnotetext{
91) Antonopoulos (2006) op. cit.; see also Ethnos “Poso Asfalis Niothoume Simera?", Ethnos (2006) I7 July.

92) There are no exhaustive analyses of the social background of the police and, in consequence, we cannot be certain about the extent to which general perceptions about migration and migrants are reflected on police perceptions. We owe this point to Georgios Papanicolaou.
}

93) P. A. J. Waddington, "Police (Canteen) Su-Culture: An Appreciation", 39(2) British Journal of Criminology (1999) 286-309.

94) Christopoulos (200I), op. cit.

95) P. van der Berghe, P. "Rehabilitating Stereotypes", 20(I) Ethnic and Racial Studies (1997) I-I6.

96) A. Triantafyllidou, "National Identity and the 'Other", 21 Ethnic and Racial Studies (1998) 593612.

97) R.A. Baron and D. Byrne, Social Psychology (9th edn, Boston, 2000).

98) H.S. Becker, Outsiders: Studies in the Sociology of Deviance (New York, 1963).

99) ESYE (200I), op. cit. 
the Greek society. ${ }^{100}$ In other words, the Albanians are the archetypal example of the "Other".

Secondly, the negative historical relationship between Greece, and Albanians and the Albanian state, primarily because of the treatment the ethnic Greek Orthodox Christian minority in Southern Albania (Northern Epirus) have received. During most of the Cold War, Albania's Greek minority was deprived of their basic human rights, including religious freedom, by Hoxha's Stalinist government. ${ }^{\text {IOI }}$ Many ethnic Greeks changed their nationality to Albanian, fearing reprisals from authorities, who considered them spies, and in the I99os leading members of Omonia, the organisation representing the ethnic Greek minority in Albania, were arrested, tried and sentenced to imprisonment for "crimes against the Albanian state". ${ }^{\text {I02 }}$ As Petrakou (200I) suggests, since a very large part of migrants come from another Balkan nation in which an ethnic Greek minority exists, migration from Albania inevitably would become a "national issue". ${ }^{\text {IO3 }}$

Thirdly, during the war in Kosovo between the Serbian security forces and the Albanian guerrilla group $U C ̧ K$ (Kosovo Liberation Army), and the bombardment of Serbian targets by NATO in 1999, a stronger anti-Albanian sentiment was consolidated due to the traditional Greek sympathy towards the Serbs (and antipathy towards the Albanians). One example being that when the Greek police were escorting Albanian migrants to the Greek-Albanian border for deportation they told them: "Go, and Clinton or NATO can provide work for you". ${ }^{104}$

Simultaneously, the social distance between Greek public in general and the migrants due to the migrants relying on established networks of compatriots, ${ }^{\text {IO5 }}$ and the excluding attitudes and practices towards migrants on the part of the Greeks have contributed to the migrant community's circumspect attitude and mistrust towards the police in Greece and consequently have contributed to the downward spiral of the relationship between the police and the migrant community. What is related to this is that there are no migrant recruits in the Greek police as a public official must have Greek citizenship, and the contact between the police and migrants takes place in stressful situations with negative encounters.

\footnotetext{
100) R. Tsagarousianou, "Mass Communication and Nationalism: The Politics of Belonging and Exclusion in Contemporary Greece", 39(2) Res Publica (1997) 271-292.

Ior) Greek Helsinki Monitor, Greeks of Albania and Albanians in Greece (Athens, 1994).

102) Human Rights Watch, "Albania: The Greek Minority", 7(4) Human Rights Watch (1995): <www. hrw.org/summaries/s.albania952.html>, accessed 8 April 2005.

103) I. Petrakou, "I Kataskevi tis Metanastefsis stin Elliniki Koinonia", in Marvakis, A., Parsanoglou,

D. and Pavlou, M. (eds.), Metanastes stin Ellada (Athens, 200I) 3I-56, p. 42.

104) Shkullaku (1999), cited by Antonopoulos (2005), op. cit., p. 256.

ros) King et al. (1998), op. cit.
} 
These negative perceptions and attitudes were reinforced by a number of highprofile cases involving migrants in the role of the hostage-taker and Greeks in the role of hostages. ${ }^{106}$ All these incidents were shown live on Greek TV, and, although police operation in one of the cases was very reassuring as to the abilities of the Greek police to protect the Greek citizens, in essence they were instrumental in "confirming" all negative stereotypes that the Greek public and of course the police have for migrants, and specifically these of "criminal" and "dangerous", and contributed to the fear of the "Other". In addition, they provided legitimate grounds for administrative measures against migrants, the so called "groom" operations in which migrants with synoptic procedures were deported to their countries. ${ }^{\text {IO7 }}$

At this point it should be mentioned that although our study has been very informative in relation to police perceptions and attitudes towards migrants in Greece, we are not in the position to offer many insights as to police discrimination against migrants in the particular study. There are very complex links between prejudice and discrimination. However, because Greece is a relatively inexperienced country in immigration, not many clear guidelines for decision making are present, and there is therefore room for discretion which may result to discrimination. ${ }^{\mathrm{I} 8}$ There are plenty of examples of discriminatory behaviour on the part of police in general, ${ }^{\text {I09 }}$ leading to the criminalisation of migrants in Greece. This may be a case that because of the contexts described before, a much larger number of criminal activities committed by migrants appears in the official criminal and police statistics, which on the one hand it may make police officers think that the bulk of criminal activities is committed by migrant offenders thus reinforcing the already existing views among the police; and on the other it may lead to a bigger focus of the police on the migrant communities in the country, by having a selective policing of migrants. As we saw earlier the detectives interviewed stopped some migrants on the basis that "they looked suspicious". In this way we have the pragmatisation of the paradox of social control "the more you search the more you find", however, only in the migrant community of the country, may that contribute to a "steady

106) These include the incidents with (Romanian) Matei Sorin in 1998, and (Albanians) Flamur Pisli and Alexi Nana in 1999. For details about the incidents see Petoussi-Douli, "Greece", in Winterdyk, J.A. and Antonopoulos, G.A. (eds.), Racist Victimisation: International Reflections and Perspectives (Aldershot, 2008).

107) Petoussi-Douli (2008) op. cit.

108) B. Bowling and C. Phillips, "Racism, Ethnicity and Criminology: Developing Minority Perspectives”, 43(2) British Journal of Criminology (2003) 269-290.

rog) See, for example, European Race Bulletin (2005) "Police Brutality Against Afghans in Athens", 50 European Race Bulletin (2005) I8. 
accumulation of discrimination" Greek criminal justice system, which however, affects the overall outcome of a case. The examples on this criminalization nexus from other contexts are many. ${ }^{\mathrm{III}}$

There are also plenty examples of police discriminations leading to the victimisation of migrants such as disrespectful attitudes and practices towards migrants and in particular Albanian migrants during stop-and-search operations, and the sporadic and unorthodox policing of migrant communities. ${ }^{\text {II2 }}$ In addition, there are clear victimizations of migrants by the police, though it should be noted that many times the distinction between the treatment of migrants during police operations and the actual victimization is blurred. ${ }^{\mathrm{II}}$ There are also deaths of migrants by the police many of which take place during deportation operations. ${ }^{\text {II4 }}$ This is a disturbing trend if one considers that the use of (deadly) force as a last resort is an important policing axiom. ${ }^{\mathrm{II}}$ Finally, the migrants receive little attention when it comes to everyday problems, exploitation, and their criminal and racist victimization. We mentioned earlier that the police neglect the victimisation of migrant women in their own homes, and according to Antonopoulos, ${ }^{\mathrm{II} 6}$ racist violence against the migrant community is not viewed as a serious - if at all - a problem by the Greek police, who are largely indifferent towards the phenomenon or even consider it as a problem for the (victimised by migrants) Greeks.

Based on our research we recommend additional research on the police attitudes and practices, prejudice and discrimination in relation to migrants in the country, the way(s) these reinforce each other as well as on the extent to which certain police attitudes and practices play a role in the over-representation of migrants in the Greek criminal justice system. Moreover, research is needed on the relationship between the individual, cultural and institutional aspects of these attitudes and practices

Iо) D.J. Smith, "Race, Crime, and Criminal Justice", in Maguire, M., Morgan, R. and Reiner, R. (eds.), The Oxford Handbook of Criminology (New York, 1994) IO4I-III7, p. IIIO.

III) S. Hall, C. Critcher, J. Clarke, T. Jefferson and B. Roberts, Policing the Crisis: Mugging, the State, and Law and Order (London, 1978).

II2) L. Fekete, "Olympic Security Plans Heighten Xenophobia”, IRR News (2004) I2 May: <www. irr.org.uk/cgi-bin/news/open.pl?id=6794>, accessed 20 July 2006.

II3) See European Race Bulletin, "AI Cites Cases of Police Violence Towards Albanians”, 39 European Race Bulletin (2002) I6; see also European Race Bulletin (2005), op. cit., p. I8.

I14) AI (Amnesty International) (2002), Greece. In the Shadow of Impunity: Ill-Treatment and the Misuses of Firearms: <web.amnesty.org/library/pdf/EUR250222002ENGLISH/\$File/EUR2502202. pdf $>$ accessed II May 2007.

II5) E. McLaughling, "Police Accountability and Black People: Into the r99os", in Cashmore, E. and McLaughlin, E. (eds.), Out of Order?: Policing Black People (London, I99I) I09-133.

I16) G.A. Antonopoulos, "Greece: Policing Racist Violence in the 'Fenceless Vineyard”, 48(2) Race \& Class (2006) 92-100. 
in relation to migrants. Simultaneously, this research should be complemented by research on migrant attitudes towards the police, as the prejudiced views of both the police and the migrants possibly contribute to a vicious cycle of prejudice, and negative attitudes (and practices).

Stop-and-search, caution, and pre-trial detentions are most certainly issues that should be the focus of inquiry of future criminological research in the country. In general terms it is imperative that over the next years the relationship between migrants, crime and the criminal justice system becomes a priority in the research agenda of the social scientists in the country. Without extensive research on the issue, something that would back up our understanding of the official statistics on ethnic differences and crime, "the figures will continue to be co-opted by either side in a long-standing debate - on the one hand as proof of large-scale discrimination throughout the whole of the criminal justice system and, on the other, as pseudo-scientific support for negative racial stereotypes". ${ }^{\text {II7 }}$

We also suggest that there should be more programmes established and initiatives undertaken towards police training on the needs of the migrant communities, and the needs of the victims of racist violence. The police should devote much more time and resources to the continuous education of police officers on the issue relating to migrants so that the degree of cultural sensitisation of the force/ service about migrants is increased. ${ }^{18} 8$ Some efforts gave been made thus far. For instance, a circular on the treatment of migrants was issued by the Chief of Police. In addition, the Ministry of Public Order in cooperation with various NGOs has organized training sessions - among other - on the treatment of migrants and human trafficking. ${ }^{\text {II }}$ Research however, suggests that training alone is not likely to overcome police prejudice. ${ }^{120}$

\footnotetext{
I17) M. FitzGerald, "Understanding Ethnic Differences in Crime Statistics”, 55 Criminal Justice Matters (2004) 22-23, p. 22.
}

I18) See W.Ph. Stol and E.J.A. Bervoets, “Policing Dutch-Moroccan Youth”, I2(3) Policing and Society (2002) I9I-200.

II9) Petoussi-Douli (2008), op. cit.

120) R.K. Wortley and R.J. Homel, "Police Prejudice as a Function of Training and Outgroup Contact: A Longitudinal Investigation”, 19(3) Law and Human Behavior (1995) 305-317. 